Check for updates

Montreal

Cite this as: BMJ 2020;371:m3861 http://dx.doi.org/10.1136/bmj.m3861 Published: 02 October 2020

\title{
Covid-19: Trump tests positive as US cases climb
}

\section{Owen Dyer}

The US president has announced that he and his wife have tested positive for the coronavirus, only hours after he claimed that the "end of the pandemic is in sight."

Donald Trump's positive result is likely to complicate his re-election plans even if his symptoms prove mild, as his campaign planned an aggressive in-person tour to close the polling gap with Democrat Joe Biden, bearing a message-unsupported by the scientific evidence-that the US has left behind the worst of the pandemic. On 2 October case numbers in the US stood at 7.28 million, with nearly 208 ooo deaths.

As recently as the morning of 1 October Trump was hoping to pack two rallies in Wisconsin that afternoon, even though his own White House Task Force had just moved the swing state into the "red" category, given its soaring case numbers, and urged residents to do everything in their power to socially distance.

But one of his closest aides, Hope Hicks, who had been travelling with Trump, began feeling ill, and by noon Trump had cancelled his appearances. Hicks tested positive later that day, and the Trumps around midnight. Aides to Trump said on Friday morning that he was showing "mild symptoms."

Like Trump, Hicks had attended a rally in Minnesota the day before, and the debate the day before that, mostly without wearing a mask. Democrats now worry that Biden could have been exposed during the debate, though he has shown no symptoms.

Trump's diagnosis came as his administration continued to play down the pandemic's worsening severity in the US and to craft policy that was at odds with the recommendations of its own scientists.

On 30 September the White House announced that cruise ships may resume operations on 31 October, overruling an order from the Centers for Disease Control and Prevention that would have kept them docked until February. The industry is important to the economy of swing state Florida.

Robert Redfield, CDC director, had told friends he might be fired this week, the New York Times reported, and he was also considering resigning if asked to oversee more policies harmful to public health. ${ }^{1}$

Reports also emerged that the CDC had watered down a report by agency scientists on a South Dakota meatpacking plant that was one of the major covid-19 hotspots in the country. ${ }^{2}$

New details emerged this week of a planned Trump administration advertising campaign that has stripped \$30om (£230m; €255m) from the CDC budget to "defeat despair, inspire hope, and achieve national recovery."3 The CDC money was taken just as Trump's own campaign ran low on funds and had to pull adverts in several key states. The amount is roughly equivalent to the Trump campaign's remaining cash on hand.

Instead of advancing a public health message, the campaign is aimed at playing down the pandemic threat, in line with Trump's re-election message. Redfield confirmed to a congressional hearing that the CDC will have no input into the advertisements' content, despite paying for them.

A former staffer for vice president Mike Pence who worked on the White House task force, Olivia Troye, revealed last week that the $\mathrm{CDC}$ had been pressured to produce a "snazzy, easy-to-read document" claiming without evidence that asymptomatic infected children were "unlikely to spread the virus."

Troye, the first White House staffer to come forward, said that Trump could not focus on the virus, was "exchanging votes for lives," and "just can't seem to care about anyone else besides himself." 4

Trump is the eighth national leader believed to have contracted the virus, joining some others who were notably dismissive of its gravity. The leaders of the UK, Brazil, Bolivia, Guatemala, Honduras, and Armenia have all had the disease, with varying symptoms.

The president of Burundi, Pierre Nkurunziza, who insisted that "God will spare Burundi" from the pandemic, is believed to have become the first national leader and first Burundian to die from covid-19 in June, though his government claimed he died from heart failure.

Kaplan S. White House blocked CDC order to keep cruise ships docked. New York Times. 30 Sep 2020. https://www.ny-

times.com/2020/09/30/health/covid-cruise-ships.html.

2 Rosenberg E. The CDC softened a report on meatpacking safety during the pandemic. Democrats say they want to know why. Washington Post. 30 Sep 2020. https://www.washingtonpost.com/business/2020/09/30/cdcmeatpacking-smithfield/\#comments-wrapper.

3 Bulik BS. "Red flag": New info on HHS' coronavirus ad campaign triggers renewed outcry. Fierce Pharma. 28 Sep 2020. https://www. fiercepharma.com/marketing/hhs-300-million-pandemic-ad-campaign-blasted-againas-new-details-leak-spokespeople-price.

4 Glasser SB. "It was all about the election": The ex-White House aide Olivia Troye on Trump's narcissistic mishandling of covid-19. New Yorker2020;18. https://www.newyorker.com/news/letter-from-trumps-washington/it-wasall-about-the-election-the-ex-white-house-aide-olivia-troye-on-trumpsnarcissistic-mishandling-of-covid-19. 